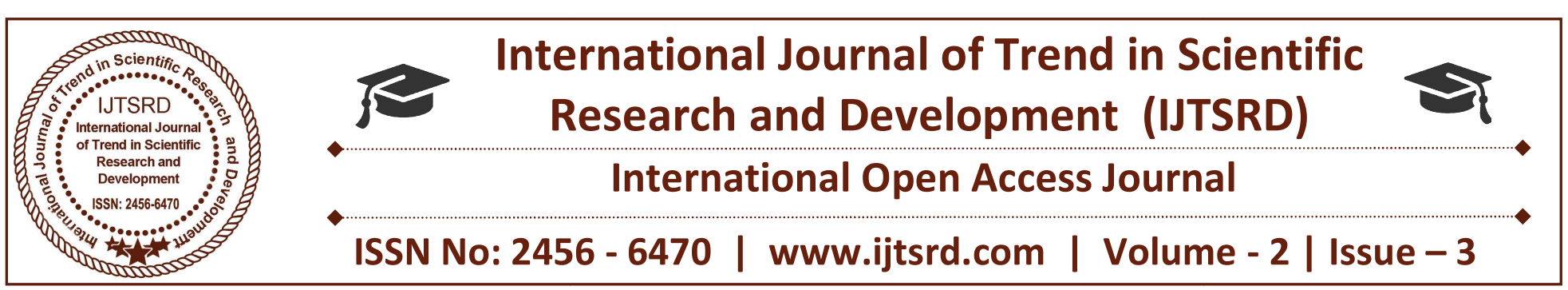

\title{
Problems Faced by Women in Agriculture and Its Allied Fields
}

\author{
Dr. Deeja. S \\ Guest Lecturer, Department of Commerce, St Gregorios \\ College, Kottarakara, Kerala, India
}

\begin{abstract}
Though the constitution of India has provided equal rights and privileges to men and women, women's lives are shaped by social customs that blind their approach. Thus there rises the need to bring women into the mainstream of development with the implementation of several developmental policies, plans and programmes. For sustained economic development and social justice, socioeconomic status of women should be improved alongside men. Kerala economy is agro-based and a major proportion of women in the labour force work in agriculture and traditional industries like cashew, coir, and handloom. A significant proportion of the labour force in the agricultural sector comprises women. Women play a vital role in building this economy. This article is an attempt to define the role of women in agriculture and its allied field.
\end{abstract}

Keywords: Women, agriculture, allied fields.

\section{Introduction}

Society is the base for overall development of a nation and the main issue hindering the development of our society is women empowerment. The condition of women was far better in ancient India. In early period Aryans treated men and women alike in all religious rituals and social functions. But condition of women has declined gradually. Over the years, there is a gradual realization of the key role of women in agricultural development and their vital contribution in the field of agriculture. Women form the most important productive work force in the economy of majority of the developing nations including India. Women often manage complex households and pursue multiple livelihood strategies.

Their activities typically include producing agricultural crops, tending animals, processing and preparing food, working for wages in agricultural or other rural enterprises, collecting fuel and water, engaging in trade and marketing, caring for family members and maintaining their homes. Many of these activities are not defined as "economically active employment" in national accounts but they are essential to the wellbeing of households. Statistical data are available regarding their participation in the agricultural sector and allied activities but their impact on the home environment has been completely ignored.

Significance of women in agriculture and its allied sector

As mentioned above, women play a significant and crucial role in agricultural development and allied fields. The nature and extent of women's involvement in agriculture varies greatly from region to region. But regardless of these variations, women are actively involved in various agricultural activities. Variations in women's participation in agricultural work depend on supply and demand factors linked to economic growth and agricultural modernization. The impact of liberalization and globalization on women is important not only because they represent almost half of the total population, but also because they face constraints, which make them less beneficial from the liberalization. Once different impacts are ascertained well designed policy responses may aid women in taking advantage of greater openness to agriculture. Mainly women are engaged in agricultural activities in three different ways depending on the socio- 
economic status of their family and regional factors. They work as:

1) Paid Labourers.

2) Cultivator doing labour on their own land.

3) Managers of certain aspects of agricultural production by way of labour supervision and the participation in post-harvest operations.

The other types of agricultural activities taken up by women include the following are:-

- Sowing

- Nursery management

- Transplanting

- Weeding

- Irrigation

- Fertilizer application

- Plant protection

- Harvesting

- Winnowing

- Storing

- Livestock

It was women who first domesticated crop plants and thereby initiated the art and science of farming. While men went out hunting in search of food, women started gathering seeds from the native flora and began cultivating those of interest from the point of view of food, feed, fodder, fibre and fuel. Women have played and continue to play a key role in the conservation of basic life support systems such as land, water, flora and fauna. They have protected the health of the soil through organic recycling and promoted crop security through the maintenance of varietal diversity and genetic resistance and security, horticulture, processing, nutrition, sericulture, fisheries, and other allied sectors. As per Census 2011, out of total female main workers, 55 per cent were agricultural labourers and 24 per cent were cultivators. However, only 12.8 per cent of the operational holdings were owned by women, which reflect the gender disparity in ownership of landholdings in agriculture. Moreover, there is concentration of operational holdings (25.7 per cent) by women in the marginal and small holdings categories.

According to 2011 World Bank Data only, $17.5 \%$ of India's Gross Domestic Product (GDP) is accounted for by agricultural production. Based on 2015 data, India is home to the fourth largest participation of Women in Agricultural Production agricultural sector in the world. It has an estimated 180 million hectares of farmland with 140million of which are planted and continuously cultivated. They make essential contributions to the agricultural development and allied and household activities and pursue multiple livelihood strategies. These activities include producing agricultural crop, cleaning animals, preparing food, working in rural enterprises, engaging in trade and marketing, caring family members and maintaining their homes. About $63 \%$ of all economically active men are engaged in agriculture as compared to $78 \%$ of women. Traditionally, women have always played an important role in agriculture- as farmers, co-farmers, wage labours and managers of farms. They have conventionally been producers of food from seed to kitchen. They carry the heavier work burden in food production and because of gender discrimination, get lower returns for their work. The multiple role of women leads to a significant contribution in real terms to the productive system. But it is unfortunate that her role is not adequately recognized and properly her contribution not qualified in the maledominated society. They have been under represented in the development process. Despite their dominance of the labour force, women in India still face extreme disadvantage in terms of pay, land rights and representation in local farmers organizations. Apart from this, women face many challenges due to limited access to productive resources in agricultural production which prevent them in enhancing their productivity.

The percentage of women who depend on agriculture for their livelihood is as high as $84 \%$. Women make up about $33 \%$ of cultivators and about $47 \%$ percent of agricultural labourers. These statistics do not account for work in livestock, fisheries and various other ancillary forms of food production in the country. In $2014,94 \%$ of the female agricultural labour forces in crop cultivation were in cereal production, while $1.4 \%$ worked in vegetable production, and $3.72 \%$ were engaged in fruits, nuts, beverages, and spicecrops. Women's participation rate in the agricultural sectors is about $47 \%$ in tea plantations, $46.84 \%$ in cotton cultivation, $45.43 \%$ growing oil seeds and $39.13 \%$ in vegetable 
production. While these cropsrequire labourintensive work, the work is considered quite unskilled. Women also heavily participate in ancillary agricultural activities. According to the Food and Agriculture Organization, Indian women represented a share of $21 \%$ and $24 \%$ of all fishers and fish farmers, respectively. A recent study conducted by Women and Population Division of FAO revealed that in developing countries women provide 70 percent of agricultural labour, 60-80 percent labour for household food production, 100 percent labour for processing the basic food stuffs, 80 per cent for food storage and 90 per cent for water and fuel wood collection for households. Women produce between 60 to 80 percent of the food in most developing countries and are responsible for half of the world's food production; therefore, women's role in food production ensures the survival of millions of people in all regions.

Most of the work that women do, such as collecting) fuel, fodder and water, growing vegetables and keeping poultry for domestic consumption tgo unrecorded in the census country. Many women whb) work on family land are not recorded as workers.) The traditional gender division of labour ensures that these women get on average 30 per cent lower wages than men. Rural women farmers perform numerous labour intensive and are also expected to collectwood from fields. Livestock play an important role in supporting women and in improving their financial situation and women are heavily engaged in this sector. An estimated two-thirds of poor livestock keepers are women in both domestic and economis) work conditions. The pattern of livestock strength is mainly influenced by various factors such as farm size, cropping pattern, availability of range-lands including fodder and pasture. Rural women earn) extra income from the sale of milk and animal6) Mostly women are engaged in cleaning of animals, sheds, watering and milking the animals. During the harvesting season, utilization of women labour is maximum, carrying bundle of harvested crop to th区) stop where threshing would be done is a heavy task which is performed mostly by women. Each bundle is carried as a head load by women, mostly bare footed, walking over the sharp shrubs of the harvested fields. Men rarely participated in this task. It was observed that majority of women is sel\&) employed and work in dangerous environments. The crop farmer plants, tills, fertilize, sprays, harvests, packs and stores the product. They are involved in activities like winnowing, weeding, grading, threshing and cleaning of field farm operations. The physical strain of female farmers in agricultural activities seems to be high because of heavy work tasks. Various activities done by women in agriculture and allied field such as manually handling loads/material, threshing, transplanting, land preparation, cleaning of animals sheds, feeding the animals and disposal of cow dung. These activities have ill effects on women health. Due to poverty and lack of required level of proteins most of women have got a very poor health.

\section{Government Initiative for Women Farmers}

Government of India has made special provisions for women farmers in various national schemes. Some of them are:

National Mission on Agricultural Extension \& Technology (NMAET) - Sub-Mission on Agricultural Extension (SAME):

Technology Management Agency (ATMA) Provides support for women Food Security Groups (FSGs), allocates Gender Coordinator'/State in the team of committed extension personnel to ensure that funds and benefits for training/capacity building and extension support etc. are provided to them in proportion to their numbers. Also provides for mandatory representation of Women Farmers in State, District, Block Farmer Advisory Committees Agri-Clinics \& Agri-Business Centers (ACABC) Provides $44 \%$ back-ended composite subsidy towards cost of project to women as compared to $36 \%$ to men

Mass Media Support to Agricultural Extension - One day specially allocated to cover areas of core competence women farmers in programs of All India Radio \&Doordarshan

Mission for Integrated Development of Horticulture (MIDH) - Specific coverage of Scheduled Caste, Scheduled Tribe and women beneficiaries for programmatic interventions and assistance for horticulture mechanization along with assistance in procuring agricultural machinery and equipments

Integrated Scheme for Agricultural Marketing (ISAM) - Provides financial assistance in Storage 
Infrastructure Projects under Agriculture Marketing infrastructure (AMI) for Registered FPOs, Panchayats, Women, Scheduled Caste (SC)/Scheduled Tribe (ST) beneficiaries or their cooperatives/Self-help groups..

9) National Mission for Sustainable Agriculture (NMSA) - At least 30\% allocation of the funds is for women farmer

10) Agricultural Insurance - Training Programmes on Gender friendly Equipment for Women farmers are to be conducted by Farm Machinery Training \& Testing Institutes and as beneficiaries at least 30\% allocation of the fund is to be made to women farmers

\section{Challenges faced by women workers}

Problems faced by female agriculturist are,

\section{Lack of deserved ownership}

Women produce 80 percent of crops and own about one percent of land. This illustrates the lack of security in ownership and they are allowed to on the infertile faction of the farm. By giving women the same access as men to agricultural resources could increase overall production in developing countries.

\section{Lack of financial supports}

Women tend to face greater challenges when it comes to securing credit. They are generally less experienced with the ins and outs of borrowing from an institution, and without assistance and support they find it difficult to access much needed funding.Women receive seven percent of the agricultural extension services and less than ten percent of the credit offered to small-scale farmers.Empowering and investing in women, specifically in rural areas, will significantly increase productivity while reducing hunger and malnutrition.

\section{3. limited awareness of advancing technology}

Women being considered the least learning faction of the society, they are deprived of the knowledge of advancing technology that can ease their work on land. If this misconception is eradicated and proper awareness is provided it could benefit the women in their work.

\section{Less market opportunities}

Lack of market research and information limit women farmers to market opportunities. Women are confined to local markets where prices are generally lower than in urban markets.

\section{Lack of infrastructure}

Access to transport and logistics would improve the mobility of women farmers and they could sell more of their farm produce in time.

\section{Discrimination at Workplace:}

However, Indian women still face blatant discrimination at their workplaces. In all agricultural activities there is an average gender wage disparity, with women earning only 70 percent of men's wage. Chauvinism is still in the rise at many workplace along with harassments that threaten omen livelihood.

\section{Suggestions}

Some of the suggestions to overcome the problems faced by women workers are

1) Providing Agricultural Training and basic education

2) Provide awareness in the society with regard to Rights and Provisions

3) Equal Job Opportunities and ensuring Equal Pay Mechanism

4) Easy Credit Facilities

\section{Conclusion}

In India the labour force is largely masculine, with only one out of every four workers being a female. Women today play a pivotal role in agriculture - as female agricultural labour, as farmers, co-farmers, female family labour and (with male out-migration, widowhood, etc.)as managers of farms and farm entrepreneurs. Three-fourths of women workers are in agriculture. Among rural woman workers, 87 per cent are employed in agriculture as labourers and cultivators increasing participation of women in the labour market in the developed and developing countries has brought out the issue of gender differentials in earnings and employment opportunities into sharp focus. The women in India, especially in rural sector are discriminated and disadvantaged in many aspects of employment such as employment diversification, quality of employment and wage earnings. The present study would explore the options for solving the problems of women labourers by making a detailed study. 


\section{REFERENCE}

1. Dev, Mahendra, S. Inclusive growth in India: Agriculture, poverty and human development. OxfordUniversity Press; 2008

2. Gulati, Ashok (2009), "Emerging Trends in Indian Agriculture: What can we learn from these? 2nd Prof. DayanathJha Memorial Lecture, National Centre for Agricultural Economics and PolicyResearch, New Delhi

3. Karl, M. (2009).Inseparable: The Crucial Role of Women in Food Security Revisited. Women in Action. No.1, 2009, PP 8-19.

4. Madhur, Gautam (2011), "India: Accelerating Agricultural Productivity Growth- Policy and InvestmentOptions", mimeo, World Bank, Washington, D.C.

5. Murthy, G. K. (2012).Women and Corporate Leadership- in of Indian Perspectives.IRACSTInternationalJournal of Research in Management \&Technology.2(4) PP 377-382.

- Rustagi,P (2010) Employment trend for women in India. International labor organization

6. Asia Pacific working paper series.(1), PP 1-40. 